\title{
Canadian Traumatologists and the Recognition of Occult Shock: Results of a National Survey
}

Tanya L Zakrison, Eman Leung, Victoria McCredie, Avery B Nathens, Christian Diez, Sandro Rizoli, Nicholas Namias

\begin{abstract}
Introduction and objective: Occult shock (OS) is important to recognize early in trauma patients, before perturbations in vital signs occur. Early trauma resuscitation is multidisciplinary in Canada. It is unclear how well Canadian traumatologists of all types recognize OS. Our objective was to explore the knowledge of OS in Canadian traumatologists.
\end{abstract}

Materials and methods: An on-line national survey was created for all multidisciplinary members of the Trauma Association of Canada (TAC). Survey questions explored the awareness, screening, prevalence, outcomes and treatment of occult and early shock.

Results: Response rate for TAC membership overall was 45\%. Overall, $78 \%$ of respondents were aware of OS and $96 \%$ felt that trauma centers should be screening for this. Traumatologists were largely uncertain as to how many patients presented to their institutions in OS, or were screened for such an entity. One out of every five Canadian traumatologists did not know how to screen for OS with over half still relying on changes in vital signs for early detection. Fifty-eight percent of Canadian traumatologists only draw blood gases on patients that are already hemodynamically abnormal. The most effective way to reverse OS remained elusive.

Conclusion: Most Canadian traumatologists recognize OS as an important clinical entity with significant morbidity and mortality. Trauma patients, however, are largely being screened late, once vital signs have changed. This may have an impact on patient care across Canada. It is unclear if this practice pattern persists throughout the Americas with inherent ramifications in quality of care and patient safety. Clinical equipoise exists in the resuscitation of OS.

Keywords: Occult shock, Survey, Awareness, Hemorrhage, Trauma.

How to cite this article: Zakrison TL, Leung $E$, McCredie V, Nathens AB, Diez C, Rizoli S, Namias N. Canadian Traumatologists and the Recognition of Occult Shock: Results of a National Survey. Panam J Trauma Critical Care Emerg Surg 2013;2(1):33-36.

Source of support: Nil

Conflict of interest: None declared

\section{RESUMEN}

Antecedentes: El choque oculto (CO) es importante de reconocer en el paciente traumatizado, antes de cambios en señas vitales. En Canadá, la resuscitación temprana del paciente traumatizado es multidisciplinaria. Todavía, no se sabe la capacidad de los traumatólogos canadienses multidisciplinarias de reconocer el $\mathrm{CO}$.
Materials y métodos: Una enquesta mutidisciplinaria fue creada e intregada a los miembros traumatólogos de la Asociación Canadiense de Trauma (ACT). Las preguntas creadas exploraron el conocimiento, exploración, resultados, y tratamiento del choque temprano y oculto.

Resultados: Recibímos respuestas de $45 \%$ de los miebros del ACT. En total, $78 \%$ de los participantes tenían conocimiento del CO y $96 \%$ tenían la opinion que los centros de trauma deberían explorarlo. Existía mucho incertidumbre en la cantidad de pacientes con el $\mathrm{CO}$. Uno de cada cinco traumatólogos canadiense no sabía como investigar el $\mathrm{CO}$, con más de la mitad guiandose con señas vitales para la detección temprana. Cinquenta y ocho porciento de los traumatólogos canadienses solo sacaron gases sanguíneas de los pacientes que eran himodinamicamente anormal. La mejor manera de normalizar el CO se quedó elusivo.

Conclusiones: La mayoria de traumatologos canadienses reconocen el CO como entidad clínica importante con una morbilidad y mortalidad significante. Sin embargo, la detección del CO ocurre tarde en los pacientes traumatizados, después de cambios en señas vitales. Eso puede impactar la atención brindada a los pacientes traumatizados en Canadá. Incertidumbre existe si este padrón clínico persiste a través de las Americas con ramificaciones importante en la calidad de la atención a los traumatizados y seguridad del paciente. La equiponderación clinica existe en la resuscitacion del CO.

Palabras claves: Choque oculto, Enquesta, Hemorragia, Trauma.

\section{INTRODUCTION}

Occult shock is the state of early hypoperfusion causing a metabolic acidosis that occurs in trauma patients, prior to changes in vital signs. ${ }^{1,2}$ This is frequently an important, early sign as it is often a refection of occult hemorrhage or class I hemorrhagic shock. ${ }^{3}$ This may represent ongoing bleeding that has yet to be identified in multiply injured trauma patients. Unrecognized bleeding has been associated, in one study of a Canadian trauma center, as the main cause of preventable, in-hospital mortality. ${ }^{4}$ The recognition and indeed the screening of occult shock is also important in patients not known to demonstrate classic hemodynamic signs of blood loss, such as the elderly. ${ }^{5,6}$ This may be due to intrinsic autonomic dysfunction or extrinsic pharmacological interference, which makes the recognition of early and occult hemorrhage challenging. Reversing occult shock in trauma patients within the first 24 hours after injury is important 
for improved patient outcomes, including a reduction in morality. ${ }^{7,8}$

Occult shock is screened through the measurement of biochemical markers, such as lactate or base deficit in an arterial or venous blood gas. ${ }^{9,10}$ Arterial blood gases are drawn during the evaluation and resuscitation of trauma patients in accordance to Advance Trauma Life Support guidelines. ${ }^{11}$ Currently, it is unclear how frequently Canadian traumatologists are screening for occult shock in trauma patients, how important they feel it is to screen for occult shock in trauma patients and the best overall method to resuscitate a patient in occult shock. It remains to be seen if Canadian traumatologists, who are exposed to a lower volume of trauma compared to their colleagues across the Americas, screen less for occult shock thus fail to recognize occult hemorrhage early. The clinical repercussions of this remain unknown.

\section{OBJECTIVES}

To investigate the understanding of occult shock among multidisciplinary Canadian traumatologists.

\section{MATERIALS AND METHODS}

\section{Survey Design}

Survey methodology was used to explore the understanding and opinions of occult shock across Canada. Basic demographic questions were asked specifying the type of training received by the participant and kind of clinical practice (urban $v s$ rural, community $v s$ academic).

We developed questions related to the identification, importance and treatment of occult shock. Questions were based on factors deemed important by trauma surgeons locally through previous qualitative methodology exploring risk factors for occult shock (unpublished data). Our survey was piloted locally to assess for internal consistency and construct validity. These questions were then administered via the internet through a survey generator (Surveymonkey $\left.{ }^{\mathrm{TM}}\right)^{12}$ over December 2011 to February 2012. The distribution list was obtained through the Trauma Association of Canada (TAC) secretariat for mass distribution. Email reminders were delivered at the two and 4 weeks mark for optimal survey participation, following the modified Dillman method..$^{13}$

Our survey began by investigating which trauma patients, upon arrival to the participant's trauma center, receive a blood gas. We then explored the opinions of Canadian traumatologists about the importance of the early recognition of occult, hemorrhagic shock. Thematic analysis included the exploration of precisely how Canadian traumatologists were identifying OS and if they felt they should indeed be identifying OS. Additionally, the optimal screening for early and acute shock was explored as was the type of treatment and resuscitation received, if any, upon the recognition of OS.

This survey received the endorsement of the Trauma Association of Canada Research Committee and was approved for Research Ethics Board with St Michael's Hospital.

\section{RESULTS}

\section{Demographics}

Eighty-six participants completed the survey, out of a total of 196 possible responses from the TAC membership representing a $44 \%$ response rate. Of these, 42 (49\%) were trauma surgeons either with or without critical care training, representing a $44 \%$ response rate from all possible member trauma surgeons. For the trauma surgeons that responded, $68 \%$ had completed a formal trauma surgery fellowship while close to half $(46 \%)$ completed a fellowship in critical care medicine. The other respondents included emergency medicine physicians, surgical residents, critical care intensivists and fellows, trauma nurses and neurosurgeons. All respondents participate in the care of the trauma patient directly or indirectly on a daily basis. Eighty percent of respondents worked in an urban area with the largest group of participants $(41 \%)$ working for more than 10 years in their field.

\section{Opinions about the Early Screening for Occult Hemorrhagic Shock in Trauma Patients}

Occult shock was defined in our survey as 'cellular hypoperfusion with normal vital signs after hemorrhage'. Over $78 \%$ of our respondents understood the definition of occult shock as metabolic acidosis in the hemodynamically normal trauma patient (Fig. 1). This was recognized as important to screen for early in the trauma patient to rule out occult hemorrhage. Overall, $88 \%$ of traumatologists felt that trauma centers should screen for occult shock, with $8 \%$ stating that they are already screening for this. Overall, therefore, $96 \%$ of Canadian traumatologists felt that occult shock should be screened in trauma centers.

\section{Who is being screened and How?}

In terms of screening for occult shock, $67 \%$ of respondents answered that biochemical markers, such as base deficit or lactate were important to use to screen for this. Important to note, however, was that up to $20 \%$ of respondents did not know what the best method was for screening for occult shock. Interestingly, when asking respondents about the best 


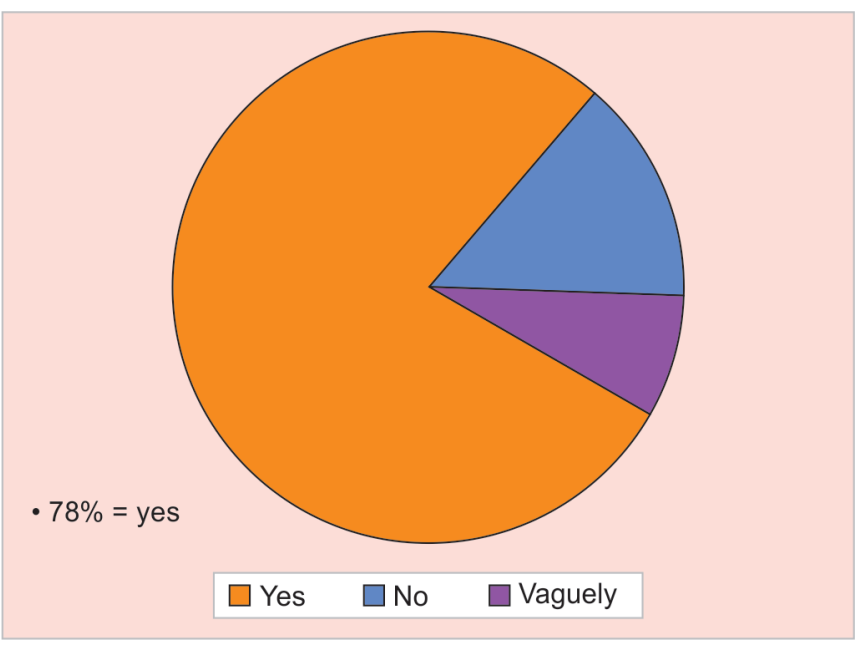

Fig. 1: Are you aware of occult shock?

way to recognize early hemorrhagic shock, only $25 \%$ stated lactate or base deficit. Up to two-third of respondents relied on a combination of clinical intuition and changes in vital signs (Fig. 2).

In order to address who is being screened for occult shock, we asked participants on arrival which traumateam activated patients receive a blood gas. Up to $67 \%$ of respondents answered that only patients who are unwell (hemodynamically abnormal, or overt shock) have a blood gas drawn. Twenty-three percent of traumatologists answered that all patients received a blood gas, while $8 \%$ answered that no gases are ever drawn (Fig. 3).

\section{The Prevalence of Occult Shock}

Many respondents did not know the prevalence of occult shock in trauma patients presenting to their centers. Most commonly, it was felt that close to $20 \%$ of all trauma patients

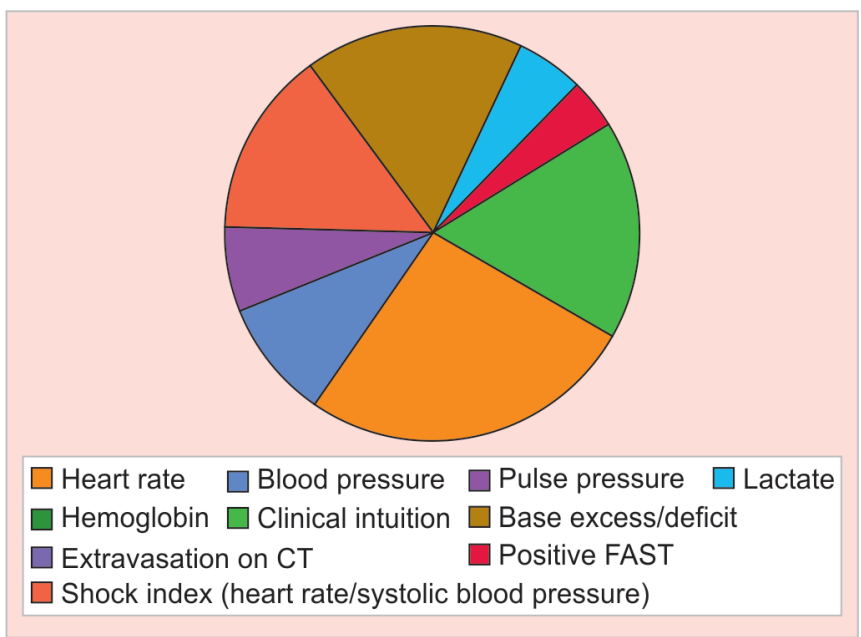

Fig. 2: Most helpful signs to recognize early hemorrhagic shock

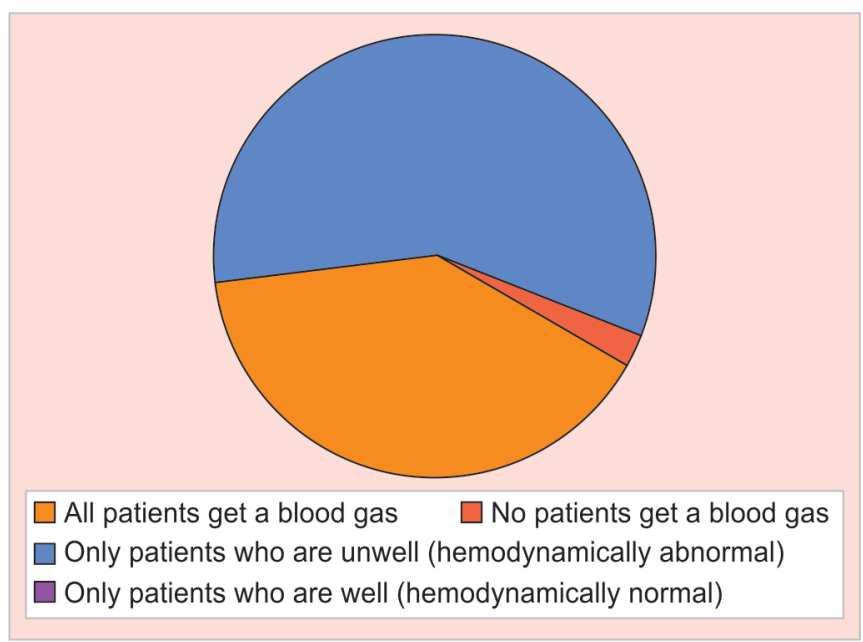

Fig. 3: Which trauma patients have an arterial blood gas drawn?

arrive in occult shock. Overall, $25 \%$ of respondents did not know the prevalence of occult shock in their institution.

\section{Resuscitation from Occult Shock}

There was no uniform agreement among Canadian traumatologists about the ideal way to resuscitate from occult shock. Most respondents agreed that the presence of occult shock was associated with worse outcomes, such as infectious and respiratory complications and lead to increased mortality. Nonetheless, clinical equipoise on the best resuscitation strategy from occult shock was demonstrated as strategies ranged predominantly from crystalloid resuscitation to observation in the Intensive Care Unit to the off-label administration of such medications as factor VII or tranexamic acid.

\section{DISCUSSION}

We surveyed close to half of all Canadian traumatologist who are members of the Trauma Association of Canada and actively engaged in the care of the trauma patient. We learned that the overwhelming majority feels that it is important to screen for occult shock if their trauma center was not already doing so. Most respondents recognized occult shock as leading to worse outcomes if not reversed in a timely fashion. Despite this sentiment, only a small fraction of trauma centers were indeed already screening for occult shock. Also, two of every three multidisciplinary traumatologists were ordering blood gases on trauma patients who were already hemodynamically abnormal, in overt shock. A significant number of traumatologists still do not know the best method of screening for occult shock and await changes in vital signs to identify early 
hemorrhage. Multidisciplinary Canadian traumatologists are not screening for occult shock early, and seem unclear as to the purpose of the blood gas and base deficit in trauma patients. It is unclear if this reflects true practice of trauma centers across Canada, or how this compares to other center across North, Central and South America or the Caribbean. The current method of resuscitation from occult shock remains unclear given the wide practice variation in methods, or even endpoints of resuscitation from occult shock. This has significant ramifications for quality of patient care and safety and merits further exploration.

\section{REFERENCES}

1. Martin JT, Alkhoury F, O'Connor JA, Kyriakides TC, Bonadies JA. 'Normal' vital signs belie occult hypoperfusion in geriatric trauma patients. Am Surg 2010;76:65-69.

2. Bradburn E, et al. High-risk geriatric protocol: Improving mortality in the elderly. J Trauma Acute Care Surg 2012;73, 435-40.

3. Davis JW, Shackford SR, Mackersie RC, Hoyt DB. Base deficit as a guide to volume resuscitation. J Trauma 1988;28:1464-67.

4. Tien HC, Spencer F, Tremblay LN, Rizoli SB, Brenneman FD. Preventable deaths from hemorrhage at a level I Canadian trauma center. J Trauma 2007;62:142-46.

5. Heffernan DS, et al. Normal presenting vital signs are unreliable in geriatric blunt trauma victims. J Trauma 2010;69:813-20.

6. Lonner JH, Koval KJ. Polytrauma in the elderly. Clin Orthop Relat Res 1995;136-43.

7. Blow O, Magliore L, Claridge JA, Butler K, Young JS. The golden hour and the silver day: Detection and correction of occult hypoperfusion within 24 hours improves outcome from major trauma. J Trauma 1999;47:964-69.

8. Ikossi DG, et al. Continuous muscle tissue oxygenation in critically injured patients: A prospective observational study. J Trauma 2006;61:780-88; discussion 788-90.

9. Porter JM, Ivatury RR. In search of the optimal end points of resuscitation in trauma patients: A review. J Trauma 1998;44: 908-14.

10. Chang MC, Rutherford EJ, Morris JA. Base deficit as a guide to injury severity and volume resuscitation. J Tenn Med Assoc 1993;86:59-61.
11. Committee on Trauma, American College of Surgeons. ATLS: Advanced Trauma Life Support Program for Doctors (8th ed). Chicago: American College of Surgeons (2008).

12. www.surveymonkey.com (first accessed Dec 05, 2011)

13. Dillman D. Mail and internet surveys: The tailored design method (3rd ed). John Wiley \& Sons, Inc. New York, NY 2009.

\section{ABOUT THE AUTHORS}

\section{Tanya L Zakrison (Corresponding Author)}

Assistant Professor, Department of Surgery, Ryder Trauma Center University of Miami, Miami, Florida, e-mail: tzakrison@med.miami.edu

\section{Eman Leung}

Quality Improvement Manager, St Michael's Hospital, Quality Improvement Unit, University of Toronto, Canada

\section{Victoria McCredie}

Clinical Associate, Critical Care Medicine, Sunnybrook Health Science Centre, University of Toronto, Canada

\section{Avery B Nathens}

Professor, Department of Surgery, Sunnybrook Health Science Centre University of Toronto, Canada

\section{Christian Diez}

Assistant Professor, Department of Anesthesiology, Ryder Trauma Center, University of Miami, Miller School of Medicine, Miami Florida

\section{Sandro Rizoli}

Professor, Department of Surgery, Sunnybrook Health Science Centre University of Toronto, Canada

\section{Nicholas Namias}

Chief of Trauma, Acting Chairman, Department of Surgery, Ryder Trauma Center, University of Miami, Miami, Florida 